\title{
United Kingdom and European Approach to Fresh Produce Food Safety and Security
}

\author{
James M. Monaghan ${ }^{1}$
}

AdDitional INDEX wORDs. microbial contamination, quality assurance schemes, codes of practice, Field to Fork

SUMMARY. Recent European outbreaks of Salmonella thompson and $S$. newport have been associated with salad rocket (Eruca vesicaria ssp. sativa) and head lettuce (Lactuca sativa), respectively. These cases emphasize the need for good agricultural and manufacturing practices for fruit and vegetables that are to be consumed raw, and the potential for large outbreaks related to fresh produce that is distributed widely. In contrast to North America, legislation in the United Kingdom (U.K.) and Europe has moved responsibility for fresh produce food safety away from government and into the supply chain. In the U.K. it is the retailers, notably Marks and Spencer with the Field to Fork codes of practice, who are driving the food safety agenda through the development of their own standards. It is retailer technologists who have been the main motivators and educators of suppliers to apply risk management to limiting or preventing microbial contamination of fresh produce.

$\mathrm{F}$ OOD-BORNE ILLNESS. The OCcurrence of food-borne illness linked with fresh produce in the U.K. is relatively low. In England and Wales, 1518 general food-borne outbreaks were registered by the U.K. Health Protection Agency (previously the Public Health Laboratory Service) between 1992 and 2000. Of these, $5.5 \%$ were linked to fresh produce (Long et al., 2002). This amounted to 3438 individual cases of infectious intestinal illness with 69 hospital admissions and one death. Over half the cases were associated with either Salmonella spp. or a group of viruses that cause viral gastroenteritis, called Norwalk-like viruses. These pathogens accounted for $41 \%$ and $16 \%$ of cases, respectively. Only one-third of the outbreaks associated with fresh produce were explained by contamination of produce at the source (i.e., in the process of growing, harvesting, or packing), rather than in the course of food preparation. Of these, lettuce was shown to be associated with a number of serious outbreaks, with 501 cases linked with three separate outbreaks; two were caused by separate strains of Salmonella typhimurium and one was caused by Shigella sonnei.

While the absolute data are probably an underrepresenta-

${ }^{1}$ Senior Lecturer-Fresh Produce, Crops Dept., Harper Adams University College, Newport, Shropshire, TF10 8NB, UK; email: jmmonaghan@harper-adams.ac.uk

\begin{tabular}{llll}
\hline $\begin{array}{l}\text { Units } \\
\text { To convert }\end{array}$ & & & \\
$\begin{array}{l}\text { U.S. to SI, } \\
\text { multiply by }\end{array}$ & U.S. unit & SI unit & $\begin{array}{l}\text { To convert } \\
\text { SI to U.S., } \\
\text { multiply by }\end{array}$ \\
\hline 29.5735 & $\mathrm{fl} \mathrm{oz}$ & $\mathrm{mL}$ & 0.0338 \\
0.3048 & $\mathrm{ft}$ & $\mathrm{m}$ & 3.2808 \\
28.3495 & $\mathrm{Oz}$ & $\mathrm{g}$ & 0.0353 \\
$\left({ }^{\circ} \mathrm{F}-32\right) \div 1.8$ & ${ }^{\circ} \mathrm{F}$ & ${ }^{\circ} \mathrm{C}$ & $\left(1.8 \times{ }^{\circ} \mathrm{C}\right)+32$
\end{tabular}

tion of the number of cases, especially for mild and brief bouts of illness, the analysis of Long et al. (2002) reports that only $1.7 \%$ of all food-borne illness could be traced to contamination of fresh produce at the source, approximately 1100 individual cases over 8 years. Bearing in mind that in the U.K. 40,000 children are injured per year on children's municipal playgrounds and play areas, consumption of fresh produce is a very safe activity!

CONSUMER CONFIDENCE IN FOOD SAFETY. In light of the absolute risk of food illness from consuming fresh produce being low, it is interesting to consider how the U.K. public perceives food safety. This must be seen in the context of a series of food scares in the 1980s. The announcement by Edwina Currie in 1988, a minister in the health department of the U.K. government, that "most of the egg production" in the U.K. was infected with Salmonella led to an understandable reduction in egg sales (Freidberg, 2004). The impact on public confidence was increased when it became clear that the government and egg producers had known about the Salmonella epi- 
demic for a year, but had not acted. This was followed up by reports of Listeria monocytogenes contamination in paté and soft cheeses (Mitchell and Greatorex, 1990).

Probably the greatest impact on public confidence resulted from the occurrence of bovine spongiform encephalopathy (BSE) in the U.K. cattle herd, first detected in 1986, and subsequently a low incidence of the fatal human disease new variance creuztfeldt jacob disease (CJD) (Powell and Leiss, 1997). The rest of Europe was also impacted by BSE. Although an embargo on U.K. beef was put in place early on, neighboring countries observed closely the problems in the U.K. and started to challenge the effectiveness of their own feed regulations (Mamerre and Narbonne, 2001).

The cultural importance of food is complex, and food and agriculture are viewed in different ways throughout Europe. Nevertheless, the consequence in the U.K., and to a lesser extent the rest of Europe, of these food scares was that consumer trust in government food regulators, government scientists, and food producers was undermined (Levidow and Morris, 2001).

U.K. Legislation. The U.K. government responded to this loss of public confidence by introducing the Food Safety Act in 1990 [Food Standards Agency (FSA), 2005]. The act was wide ranging and covered all aspects of the food supply chain. Most farmers were now considered to be running food businesses and subject to new enforcement measures. A key element was the bypass provision that allowed a prosecutor to bypass the immediate offender (e.g., retailer) and proceed against the real offender (e.g., food processor). In defense, the prosecuted would have to demonstrate that they "took all reasonable precautions and exercised all due diligence to avoid the commission of the offence." This due diligence defense has had a marked effect on the way retailers manage risk to their brands through the supply chain. In effect, the government passed the responsibility for food safety along the supply chain. The dominance of U.K. multiple retailers, with $80 \%$ of fresh produce market share, and the strength of their own label brands has led to different emphasis in this application. As a result a number of different retailer codes of practice have been developed, most notably by
Tesco (Tesco PLC, Cheshunt, U.K.) and Marks and Spencer (Marks and Spencer PLC, London).

This clear connection between responsibility for food safety and brand integrity has led to a focused approach by food retailers. The effect of this was recognized in the 2005 U.K. parliamentary elections when the Health Minister Patricia Hewitt stated “... we've got tougher hygiene laws and standards in food factories than we have for people who are very, very seriously ill in hospital."

Primary producers have also responded to the need to reinstate consumer confidence in food safety and provide a due diligence defense. One way that this has been attempted is through the development of quality assurance (QA) schemes [e.g., EurepGAP established by the Euro-retailer produce working group (EUREP) in 1997 to outline standards of good agricultural practice (GAP) (EurepGAP, 2005) and the Assured Produce Scheme (Assured Produce, 2005)]. QA schemes have proliferated to the level that the burden of paperwork has become onerous for producers and there is a move to consolidate schemes "under one umbrella." It may be considered that the producers are trying to protect and improve the brand of U.K. producers much the same way as retailers are protecting and improving their own brands through codes of practice.

As a further act to move food safety from direct government control, the U.K. government in 2000 established the FSA as an independent food safety watchdog (FSA, 2005). The aims of the FSA for 2001-06 highlight the way that government has refocused on the consumer:

1. protect the public's health and consumer interests in relation to food $20 \%$

2. reduce food-borne illness by fully

3. help people to eat more health-

4. promote honest and informative labeling

5 . promote best practice food law

6. improve the enforcement of

7. earn people's trust

European Legislation. The response of European legislation has been slower, but looks similar to the U.K. approach and is now coming into force. In 2002, the European
Parliament passed the European Union (EU) General Food Law (EC) No. $178 / 2002$, to be fully implemented by all member states by 2007 (Europa, 2005). The regulation set up the European Food Safety Authority (EFSA) to monitor and enforce adherence to the new guidelines and, like the U.K., established the basic principle of primary responsibility for ensuring compliance with food law. In particular, the safety of the food rests with the food business.

Another key component of the law is traceability. This has now been implemented and from 1 Jan. 2005, it must be possible to trace and follow food, feed, and ingredients through all stages of production, from the farming sector to processing, transport, storage, distribution, and retail to the consumer. This is being achieved in practice through businesses identifying the immediate supplier of the product in question and the immediate subsequent recipient, with the exemption of retailers to final consumers (one step back, one step forward). The name, address of producer, nature of products, and transaction date must be systematically registered within each operator's traceability system; this information must be kept for a period of 5 years.

Marks and Spencer Field to Fork. The legislative changes over the last 15 years, outlined above, have moved responsibility for fresh produce food safety to the retailer. The requirement for a robust due diligence defense has led to retailers developing, implementing, and managing their own codes of practice. It is generally accepted that the retailer which has focused most closely on food safety is Marks and Spencer PLC. In 2003, Marks and Spencer's new code of practice, called Field to Fork, was launched with the following introduction: "The Brand Values of Quality, Safety and Trust are reflected throughout these new codes, which now encompass wider aspects of production than our previous codes of practice. They represent a leading standard against which all other standards will be measured."

Field to Fork covers all aspects of the growing and packing of fresh produce, with sections on pesticide management, food safety, organic produce, traceability, environment, packing, and genetically modified organisms (GMOs).

In an industry where new require- 
ments are seen as yet more paperwork, Marks and Spencer initially looked to utilize an existing system and instigated a review of worldwide systems. The main findings were that there were hundreds of schemes in place, but while there was good coverage of GAP and pesticides, there were few which focused on food safety and none adequate for Marks and Spencer. As a result, Field to Fork was developed as a new code of practice in consultation with representatives from the supply base. Involvement of the supply base was a key factor in acceptance and implementation by suppliers. In addition, it was clear from the outset that some of the areas were being considered for the first time and that recommendations may need to change in the light of information collected through the implementation of new monitoring requirements within Field to Fork.

Some of the key areas focusing on fresh produce food safety are outlined below.

Field to Fork AND FRESH PRODUCE SAFETY. The starting point for Field to Fork is that there is no guarantee of pathogen-free produce. Therefore, it is important to 1) understand the risks of contamination, 2 ) identify sources of contamination, and 3 ) minimize them. Although Field to Fork has been developed following the principles of hazard analysis critical control point (HACCP), the reality of crop production means that, in contrast to a high-care food factory, in many instances it is not possible to eliminate risk at a critical control point, only to minimize it.
Crops are categorized by risk from 1-4, with greatest care needed with category 1 crops. These are those crops eaten raw with no protective skin that is removed before eating and have a significant risk or history of pathogen contamination. The list includes any vegetable leaf that could be eaten raw [e.g., lettuce, green onions (Allium fistulosum), fresh and frozen herbs].

Category 2 crops can be eaten raw and either have no protective skin that is removed before eating or have some risk or history of pathogen contamination. The list includes broccoli (Brassica oleraceavar. italica), cabbage (Brassica oleracea var. capitata), and carrot (Daucus carota).

Category 3 crops can be eaten raw, either have a protective skin or grow clear of the ground or have no significant history of pathogen contamination. This list includes crops such as tree fruit, blackcurrant (Ribesnigrum), green beans (Phaseolus vulgaris), and pineapple (Ananas comosus).

Category 4 are those crops that are always cooked before eating [e.g., asparagus (Asparagus officinalis), brussels sprouts (Brassica oleracea var. gemmifera), and eggplant (Solanum melongena)].

Managing Potential routes of CONTAMINATION. The potential routes of contamination of fresh produce are through contaminated compost/soil, water, workers either harvesting or packing crops and wildlife. It is these areas that are to be controlled.

Soil/composted manure. Different inputs are considered and risk assessed, and minimum timescales stipulated between application and planting of single or multiple harvest crops (see Table 1). Some time scales are reduced through supporting decisions with formal microbiological testing. The samples must be analyzed in an accredited laboratory using Marks and Spencer-approved methods. Samples must be taken to validate the completion of the composting process and the results must be available before applying the compost or manure. Every batch must be sampled. The samples must be taken from three different locations within the pile (i.e., from the core, the outer surface and midway between these two points). One mixed $/ \mathrm{com}^{-}$ posite $100 \mathrm{~g}$ sample must be tested for the absence of Salmonella spp. in $50 \mathrm{~g}$ and enumeration of Escherichia coliper gram. In larger piles, the three samples must be tested separately rather than as a composite.

The presence of Salmonellaspp. in $50 \mathrm{~g}$ or E. coli at $>100 \mathrm{cfu} / \mathrm{g}$ results in the pile being composted for another 6 months. Further samples must be taken as above at the end of this period.

WATER. Field to Fork aims to manage risk of contamination from water used for irrigation, mixing pesticides, fertigation, cleaning or for anything else which brings it into contact with the edible parts of the crop. The microbiological quality of the water must be determined by regular sampling to monitor for coliforms with automatic reporting of the presence of $E$. coli. How often it is sampled will vary according to the stability of the source and history of consistent results, but must be at least once per month.

Table 1. Guidelines developed by Marks and Spencer stipulating for category $1-4$ crops the minimum period of months that must elapse between soil exposure to potential contaminants and crop drilling or planting for single harvest crops, or between soil exposure to potential contaminants and first crop harvest for recurrent harvest crops.

\begin{tabular}{|c|c|c|c|c|}
\hline \multirow[b]{2}{*}{ Soil contamination risk } & \multicolumn{4}{|c|}{ Minimum time after soil exposure (months) } \\
\hline & $\begin{array}{c}\text { Category } \\
1\end{array}$ & $\begin{array}{c}\text { Category } \\
2\end{array}$ & $\begin{array}{c}\text { Category } \\
3 \\
\end{array}$ & $\begin{array}{c}\text { Category } \\
4\end{array}$ \\
\hline $\begin{array}{l}\text { Sewage sludge and any waste from birds or mammals (other than manure) applied } \\
\text { to cropping land }\end{array}$ & 60 & 60 & 60 & 60 \\
\hline Raw animal manure applied to cropping land & 24 & 18 & 18 & 12 \\
\hline $\begin{array}{l}\text { Animal manure applied to cropping land after treatment following Chilled Food Assn } \\
\text { (CFA) guidelines (Goodburn, 2002) but not supported by microbiological testing }\end{array}$ & 18 & 12 & 12 & 0 \\
\hline $\begin{array}{l}\text { Animal manure applied to cropping land after treatment following CFA guidelines } \\
\text { (Goodburn, 2002) and supported by microbiological testing }\end{array}$ & 12 & 6 & 6 & 0 \\
\hline $\begin{array}{l}\text { Green waste applied to cropping land after composting generating core temperatures } \\
\text { of }>55^{\circ} \mathrm{C}\left(131.0^{\circ} \mathrm{F}\right) \text { over } 3 \mathrm{~d} \text { but not supported by microbiological testing }\end{array}$ & 3 & 0 & 0 & 0 \\
\hline $\begin{array}{l}\text { Green waste applied to cropping land after composting generating core temperatures } \\
\text { of }>55{ }^{\circ} \mathrm{C} \text { over } 3 \mathrm{~d} \text { and supported by microbiological testing }\end{array}$ & 0 & 0 & 0 & 0 \\
\hline Use of land for intensive grazing & 18 & 12 & 12 & 6 \\
\hline
\end{tabular}


Irrigation water sources must be protected against contamination from raw animal manure or sewage sludge applied to adjacent land with a recommended minimum buffer zone of $50 \mathrm{~m}$.

At the outset of Field to Fork it was a target that water quality must be free from E. coli per $100 \mathrm{~mL}$ for all category $1-3$ crops.

Workers. All workers whether for harvesting or packing must have training in basic hygiene as part of the induction for new staff. The trainer must sign a record of the training given and the worker must also sign to confirm they understood it.

All new staff must complete a preemployment medical questionnaire and a suitably trained manager must check it to ensure there are no health issues which could pose a food-safety risk. In countries where discrimination or privacy laws prevent this, the employee should obtain a doctor's certificate to confirm their fitness to work.

Sufficient hand-washing units and field toilets must be conveniently located within access of the crop fields. Hand-washing units should have drinking quality water, odorless soap, hand towels (preferably disposable paper type), and a hand disinfectant (e.g., alcohol gel) dispenser.

The following personal hygiene rules apply to staff whose work involves handling the edible parts of crops:

- Everyone must wash their hands with soap and water, dry them and disinfect them before starting work, after using the toilet and after breaks.

- Anyone wearing gloves must change them regularly. If re-using them, wash them after breaks, as with hand washing.

- Anyone who works closely with the crop (e.g., picking by hand) must cover their hair with something suitable such as a baseball cap.

- Anyone suffering any gastrointestinal illness must report it to the manager, and not handle crops until at least $48 \mathrm{~h}$ after their last episode of vomiting or diarrhea.

- Anyone with any wounds on the exposed parts of their hands or arms must cover them with a blue waterproof bandage. As an extra precaution, they must wear gloves over any bandage on their hands.

- No one must smoke unless they are in designated areas (e.g., headlands).
- There needs to be a company policy on jewelry. This policy must be practical, but take into consideration the contamination, hygiene, or infection risks associated with wearing watches, earrings, studs, and other body piercing.

-Eating must only be allowed in designated areas away from crop growing and harvesting. There must be sufficient waste bins for food debris and rubbish.

- Personal items such as cigarettes and newspapers must not be taken into the crop growing area.

- Heavily perfumed cosmetic or toiletry products must not be worn.

It is very important to keep daily records to show everyone is following the above hygiene rules.

Personal protective Clothing. Businesses worldwide have accepted the need for hygiene management and personal protective clothing within packhouses, but Field to Fork has addressed hygiene standards where product is packed in the field or greenhouse.

Where crops are being packed into final packaging (i.e., the final handling of the produce) at high temperatures (greenhouse and field packing rigs), the preferred option is a removable bib or apron worn over personal clothing. In addition, alternative styles of hair covering are allowed (e.g., baseball caps with Velcro fastenings) so long as there is no history of hair complaints from customers.

In an attempt to minimize risk from contamination of protective clothing outside of the site, all protective clothing, including head covering, must not leave the site for any reason except laundering by a contractor. It is not acceptable for personnel to launder their own protective clothing at home.

Wilduife. The final potential source of contamination is wildlife. It is clearly impractical and very undesirable to eliminate all potential wildlife contaminators. Consumers expect growers to be environmentally benign in their production of crops. Nevertheless, growers of category 1 crops should make efforts, such as fencing and scarers, to discourage wild animals from entering the growing area. Ideally these crops should not be grown in fields with public access, such as footpaths or bridleways. However, it is acceptable if it can be demonstrated that there is some management and control of public access to field margins.

\section{Summary}

This paper presents an overview of the drivers improving the management of food safety and the responses of the fresh produce industry. One response has been the development of Field to Fork by Marks and Spencer in 2003. This has led to debate among industry stakeholders around the extent to which risk can be tolerated in some crops. As more information becomes available, as a result of monitoring required from Marks and Spencer suppliers, the industry is starting to quantify absolute risk allowing management of the areas that pose real rather than perceived risk to consumers.

\section{Literature cited}

Assured Produce. 2005. The scheme: The Assured Produce scheme (APS). 20 Apr. 2005. <http://www.assuredproduce.co.uk/ Aproduce $/>$.

EurepGAP. 2005. About EurepGAP. 28 May 2005. <http://www.eurep.org/Languages/ English/about.html>.

Europa. 2005. General food law-Principles. 28 May 2005. <http://ec.europa. $\mathrm{eu} / \mathrm{comm} / \mathrm{food} /$ food/foodlaw/principles/ index_en.htm>.

Food Standards Agency. 2005. Food Standards Agency, how we work. 28 May 2005. <http://www.food.gov.uk/aboutus/how we_work $/>$.

Freidberg, S. 2004. French beans and food scares: Culture and commerce in an anxious age. Oxford Univ. Press, New York.

Goodburn, K. 2002. Microbiological guidance for produce suppliers to chilled food manufacturers. Chilled Food Assn., Kettering, U.K.

Levidow, L. and C. Morris.2001. Science and governance in Europe: Lessons from the case of agricultural biotechnology. Sci. Public Policy 28:346-60.

Long, S.M., G.K. Adak, S.J. O'Brien, and I.A. Gillespie. 2002. General outbreaks of infectious intestinal disease linked with salad vegetables and fruit, England and Wales, 1992-2000. Communicable Dis. Public Health 2002 5:101-105.

Mamerre, N. and J.F. Narbonne. 2001. Toxique affaires: De la dioxine a la vache folle. Editions Ramsey, Paris.

Mitchell, V.W. and M. Greatorex. 1990. Perceived consumer risk in the UK food market. Brit. Food J. 92: 16-22.

Powell, D.A. and W. Leiss. 1997. Mad cows and mothers milk: The perils of poor risk communication. McGill-Queen's University Press, Montreal. 